\title{
ANALISIS ASPEK KEJIWAAN TOKOH UTAMA NOVEL HATI SUHITA KARYA KHILMA ANIS (TINJAUAN PSIKOLOGI SASTRA)
}

\author{
Nanda Maulana Hasmi \\ e-mail: nandamaulana21@gmail.com \\ Prodi Tadris Bahasa Indonesia \\ Institut Agama Islam Darussalam Blokagung Banyuwangi
}

\begin{abstract}
Abstrak
Karya sastra berusaha menggambarkan kehidupan manusia, tidak hanya dalam hubungan dengan manusia lain, tetapi juga hubunganya dengan dirinya sendiri melalui hubungan peristiwa batin. Salah satu bentuk karya sastra adalah novel. Lahirnya novel merupakan hasil kreatif pengarang dalam mengolah cerita tentang kehidupan lengkap dengan berbagai konflik di dalamnya. Karena penelitian ini dimaksudkan sebagai kajian psikologi sastra untuk mencapai aspek kejiwaan tokoh utama novel Hati Suhita karya Khilma Anis maka yang akan dikemukakan adalah struktur cerita yang dekat hubungannya untuk pengukapan kejiwaan tokoh utama. Struktur cerita tersebut adalah tokoh dan penokohan. Serta latar cerita. Metode kualitatif prosedur penelitian yang menghasilkan data deskriptif kualitatif berupa kata-kata tertulis atau lisan dari orang-orang dan perilaku yang diamati. Bagaimana data yang sebanyak-banyaknya itu diambil akan mampu menjadi subjek penelitian, adalah tergantung pemanfaatan teknik penelitian. Sedangkan pendekatan adalah sebuah perspektif penilaian sastra. Pendekatan merupakan ruang lingkup penelitian sastra. Bentuk, isi, dan sifat sastra sebagai subjek kajian. Sampai saat ini, tampaknya dalam penelitian sastra seringkali ada kerancuan antara penggunaan istilah metode, teknik, dan pendekatan. Akibatnya ada ketumpangtindihan wilayah penelitian sastra. Metode semestinya menyangkut cara yang operasional dalam penelitian. Metode telah membutuhkan langkah penelitian yang pantas diikuti. Hasil penenelitian yang ditemukan oleh peneliti berupa watak tokoh utama dan konflik kejiwaan pada novel Hati Suhita karya Khilma Anis. Watak tokoh Suhita baik,tawadhu,pintar. Al Birruni tegas, gampang berubah. Rengganis cantik, pintar. Aruna baik, periang. Kang Dharma tenang, dewasa. Dan konflik kejiwaan tokoh Suhita sedih. Al Birruni tidak tega, Rengganis tahu diri, Aruna sedih, dan Kang Dharma tenang. Kesimpulan dari novel Hati Suhita yang diteliti adalah setelah tokoh Suhita mengalami periode yang kelam dia tidak akan kembali ke periode sebelumnya, karena psikologi kejiwaannya telah mengalami kisah yang lengkap dari sebuah perjalanan hidup manusia. Jadi dengan dilakukannya penelitian maka penulis menyarankan bahwa: pertama, kepada penelaah sastra disarankan untuk mengkaji lebih mendalam tentang adanya nilai-nilai tersirat maupun tersurat dalam novel Hati Suhita karya Khilma Anis, karena dengan begitu kita sebagai pembaca dapat memahami pesan pengarang dan karyanya secara totalitas.
\end{abstract}

Kata Kunci: Watak Tokoh, Kejiwaan, Latar 


\begin{abstract}
Literary work tries to describe human life, not only in relation to other humans, but also in relation to itself through the relationship of inner events. One form of literary work is novel. The birth of the novel is the creative result of the author in processing a story about life complete with various conflicts in it. Because this research is intended as a study of literary psychology to achieve the psychological aspects of the main character in the novel Hati Suhita by Khilma Anis, what will be put forward is the structure of the story which is closely related to the psychological exposure of the main character. The story structure is the characters and characterizations. As well as the story setting. Qualitative method. Namely, research procedures that produce qualitative descriptive data in the form of written or spoken words from people and observed behavior. How as much data as possible will be able to become the subject of research depends on the use of research techniques. While the approach is a literary assessment perspective. The approach is the scope of literary research. The form, content, and nature of literature as the subject of study. Until now, it seems that in literary research there is often confusion between the use of the terms method, technique and approach. As a result, there are overlapping areas of literary research. The method should involve the operational means of research. The method requires research steps that are worth following. The research results found by the researcher were in the form of the character of the main character and psychological conflicts in Khilma Anis' novel Hati Suhita. Suhita's character is good, tawadhu, smart. Al Birruni is firm, easy to change. Rengganis beautiful, smart. Aruna is good, cheerful. Kang Dharma is calm, mature. And the psychological conflict of Suhita's character is sad. Al Birruni didn't have the heart, Rengganis knew himself, Aruna was sad, and Kang Dharma was calm. In connection with conducting the research, the writer suggests that: first, literary reviewers are advised to examine more deeply the implicit and explicit values in Khilma Anis' novel Hati Suhita, because then we as readers can understand the author's message and his work in totality.
\end{abstract}

Keywords: Character Character, Psychiatric, Background

\title{
A. Pendahuluan
}

Karya sastra adalah suatu seni kreatif pengarang. Terciptanya sebuah karya sastra sebagai hasil imajinatif kreatif pengarang sehingga terbentuk dunia imajinatif. Di dalam dunia imajinatif pengarang sebelumnya berkuasa mebicarakan, mengupas, dan bahkan memutarbalikan kehidupan manusia. Namun seorang pengarang yang baik akan dapat menampilkan pengalaman hidup manusia berdasarkan situasi dan kondisi yang tengah berlangsung di tengah masyarakat. 
Karya sastra berusaha menggambarkan kehidupan manusia, tidak hanya dalam hubungan dengan manusia lain, tetapi juga hubunganya dengan dirinya sendiri melalui hubungan peristiwa batin. Salah satu bentuk karaya sastra adalah novel. Lahirnya novel merupakan hasil kreatif pengarang dalam mengolah cerita tentang kehidupan lengkap dengan berbagai konflik di dalamnya.

Penelitian merupakan serangkain kegiatan atau proses sistematis dan menggunakan metode ilmiah untuk memecahkan masalah dengan dukungan data sebagai landasan untuk mengambil kesimpulan, Wuradji (Wiyatmi, 2011: 68). Dalam kaitannya dengan penelitian sastra, maka kegiatan tersebut diarahkan untuk memecahkan masalah dengan karya sastra. Masalah-masalah yang dapat muncul dan berkembang dari keberadaan karya sastra, yang dapat dijadikan fokus penelitian antara lain dalam hubunganya dengan pengarang, pembaca, realitas, maupun karya sastra itu sendiri (Wiyatmi, 2011: 68).

Menurut Wellek dan Warren (dalam Wiyatmi, 2011: 18) secara sederhana kata sastra mengacu pada dua pengertian, yang pertama karya sastra dan yang kedua ilmu sastra, merupakan salah satu cabang dari ilmu pengetahuan. Jika digunakan dalam kerangka karya sastra, sastra merupakan hasil dari sebuah karya seni yang diciptakan pengarang bermediakan bahasa. Salah satu diantara jenis karya sastra adalah novel. Berbagai fenomena kehidupan manusia dapat dijumpai dalam cerita novel, mulai dari permasalahan kehidupan yang umum hingga permasalahan kehidupan yang bersifat pribadi, karena dalam novel dapat diketahui lika- liku kehidupan manusia. Luar karya sastra. Dalam hal ini penulis akan mengkaji tentang psikologis tokoh utama dalam novel Hati Suhita karya Khilma Anis.

Novel yang dipilih dalam penelitian ini adalah novel Hati Suhita karya Khilma Anis. Novel Hati Suhita ini sarat dengan nilai-nilai kemanusiaan dan layak untuk dikaji. Penulis menyampaikan kisah yang mengharukan serta banyak pesan dan juga hikmah yang mengalir dalam cerita ini. Perjuangan tokoh utama yang ada dalam cerita ini merupakan sosok yang memegang teguh prinsipnya sebagai seorang pecinta sejati. 


\section{B. Metode Penelitian}

Dalam penelitian ini peneliti menggunakan metode kualitatif. Yakni prosedur penelitian yang menghasilkan data deskriptif kualitatif berupa katakata tertulis atau lisan dari orang-orang dan perilaku yang diamati, Bodgan dan Taylor (dalam Prastowo, 2012: 22). Dalam penelitian kualitatif prosedur untuk menghasilkan data deskriptif berupa data simak dan catat pada pengamatan video (Ma'arif, 2021:158).

Bagaimana data yang sebanyak-banyaknya itu diambil akan mampu menjadi subjek penelitian, adalah tergantung pemanfaatan teknik penelitian. Sedangkan pendekatan adalah sebuah persfektif penilaian sastra. Pendekatan merupakan ruang lingkup penelitian sastra. Wilayah ini berhubungan dengan aspek-aspek kejiwaan dan diungkap dalam penelitian. Pendekatan akan membingkai objek apa saja yang mungkin akan diungkap dalam penelitian. Itulah sebabnya, pendekatan juga sering dinamakan sebuah model penelitian (Endaswara, 2013: 8).

Dalam literatur metodologi penelitian, istilah kualitatif tidak hanya lazim dimaknai sebagai jenis data. Tetapi juga berhubungan dengan analisis data dan interprestasi antar objek kajian. Secara historis implementasi penelitian kualitatif berkenaan dengan pengukuran tingkatan dengan satu ciri tertentu.

Namun penelitian kualitatif menunjukan pada segi ilmiah yang dipertentangkan kuantum (jumlah). Maksudnya, penelitian kualitatif tidak dimaksudkan untuk mengadakan perhitungan secara kuantitas. Hal ini berbeda dengan pengamatan pada penelitian kuantitatif yang pengamatannya berdasarkan perhitungan prestasi, rata-rata, chi, square, dan berbagai perhitngan statistik lainnya, Bodgan dan Taylor (dalam Prastowo, 2012: 2122).

peneliti mulai mencatat atau menghitung dari satu, dua, tiga, dan seterusnya. Dengan pertimbangan yang dangkal seperti itu, lalu peneliti menyatakan bahwa penelitian kuantatif mencakup setiap jenis penelitian yang berdasarkan pada perhitungan presentasi, rata-rata, chi kuadrat, dan perhitungan statistik lainnya. Dengan istilah lain, peneliti kuantatif 
melibatkan diri pada perhitungan, angka, atau kuantitas. Sementara dipihak lain kualitas menunjuk pada segi alamiah yang dipertimbangkan pada kuantum atau jumlah tersebut. Atas dasar pertimbangan inilah, kemudian penelitian kualitatif tampaknya diartikan sebagai penelitian yang tidak mengadakan perhitungan.

\section{Hasil Dan Pembahasan}

Alina Suhita, perempuan dari trah darah biru pesantren dengan moyang pelestari Jawa, sejak remaja terikat perjodohan. Ketika hari pernikahan tiba, Gus Birru suaminya, menumpahkan kekesalan dengan tidak mau menggauli Suhita. Tinggal dalam satu kamar tapi tempat tidur terpisah sejak malam pertama pernikahan. Tanpa perbincangan apalagi kehangatan, namun bisa bersandiwara sebagai pasangan pengatin mesra ketika di luar.

Alina Suhita begitu patuh. Khas tawadhu' santri. Baginya, mikul duwur mendem jeru menjadi pegangan yang mutlak diterima dan dilakkukan tanpa reserve. Gejolak hasrat seorang istri yang disambut penolakan terangterangan suami, tepat ketika perempuan masa lalu suami muncul menjalin komunikasi layaknya sepasang kekasih, adalah penderitaan yang mengiringi konflik batinnya selama beberapa purnama.

Namun yang tersemat dalam nama Suhita, adalah kekuatan tiada bandingan. Suhita menelan semua getir itu sendirian. Merebahkannya di dalam sujud, melantunkannya dalam ayat-ayat Tuhan yang ia hapal seluruhnya, juga tengadah do'a di tempat orang-orang disemayamkan.

Aku tidak tahu apa yang ada di pikiran Mas Birru tadi pagi itu aku begitu bahagia. Segala sesuatu jadi tampak indah. Seperti sore ini. Rumah Jawa ini terasa begitu memikat hatiku. Aku memang jarang duduk disini. Mas Birru jarang mengajakku. Seringnya Ummik mengajakku kesini untk menyimak hapalanku atau ummuk sendiri yang memintaku menyimak hapalannya. Selama ini mataku yang sendu tak mampu menangkap keindahan yang melingkupi tempat ini.

Setiap kali berbelok ke gerbang pesantrenku, aku selalu enggan. Aku selalu butuh bermenit-menit untuk diam di dalam mobil dulu sampai hatiku 
tenang. Lalu turun dari mobil dan masuk rumah dengan langkah berat. Kalau tidak ingat ummik, rasanya aku ingin tinggal di kota lain, kalau perlu ke negara lain. Daripada aku terus-terusan menghadapi sesuatu yang membosankan. Dia, istriku, yang kunikahi tanpa sedikitpun rasa cinta. Dia ada di kamarku sepanjang waktu. Tidak pernah beranjak. 24 jam tanpa jeda dan tanpa sekat. Dia ada di hadapnku sepanjang siang dan malam.

Hari ini aku tahu, tidak sia-sia Mbah Kung menyematkan nama salah satu penguasa perempuan di kerajaan Majapahit dalam namaku, Suhita. Perang di hatiku sepanjang tujuh purnama ini begitu dahsyat. Kebekuan dan keangkuhan suamiku telah membuat hatiku berdarah-darah. Penolakannya sudah membuatku tersungkur tak berdaya. Tapi aku tidak pernah menyerah. Aku melawannya dengan kelembutan, dengan ilmuku, sekaligus dengan puja pintaku.

Hari ini ia sudah takluk. Aku telah memenangkan pertarunganku. Akulah Alina Suhita, yang kini bertahta di kerajaan hatinya.

$\mathrm{Aku}$ ingin menyentuh wajahnya tapi kutahan karena masih ingin meneruskan mengaji. Jadi aku hanya diam mengamati dan merasai. Aku sangat bahagia Mushaf di tanganku. Mas Birru di pangkuanku. Al Anwar di pikiranku. Abah ummik di hatiku. Dan benih Mas Birru, baru saja, di rahimku.

Tabah = Karena bisa menerima semua yang di lakukan Mas Birru terhadapnya.

Terdapat dalam kutipan:

Kutipan Percakapan: "Aku tak mengerti sampai kapan aku bisa bersila merapal do'a, sepanjang apapun kulafalkan pinta, aku tak mungkin sampai pada pemahaman mengapa aku begitu mencintai Mas Birru. Walau ia begitu dingin"

Keterangan tokoh lain: "Dialah Alina Suhita. Yang sore ini tampak tak berdaya. Seperti teratai yang diamuk ganasnya cuaca. Matanya tahu aku akan memikirkanya. Tapi dia tak pernah membiarkan kekhawatiran menyusup diantara kami. Ia seperti ratu. Melindungi keraajaannya. Melindungi kehormatannya. Ia memang Dewi Suhita" 
Pintar $=$ Karena bisa memahami budaya Jawa dengan baik.

Terdapat dalam kutipan:

Keterangan tokoh lain: "Dia menyukai wayang, menikmati itu sebagai sebuah selingan lalu jadi pedoman. Ia memang mewakili keanggunan dan kelembutan karakter perempuan Jawa. Jadi menurutku, buku-buku tentang dunia Jawa sangat penting untuknya. Tapi dia, selalu berhati-hati. Setiap aku memanggilnya, kewaspadaannya padaku membuatku semakin menghormatinya. Dan tentu saja, mengaguminya"

Tawadhu $=$ Karena sangat menghormati sang suami.

Keterangan tokoh lain: “Alina Suhita begitu patuh. Khas tawadhu' santri. Baginya, mikul duwur mendem jeru menjadi pegangan yang mutlak diterima dan dilakkukan tanpa reserve. Gejolak hasrat seorang istri yang disambut penolakan terang-terangan suami, tepat ketika perempuan masa lalu suami muncul menjalin komunikasi layaknya sepasang kekasih, adalah penderitaan yang mengiringi konflik batinnya selama beberapa purnama hilang"

Susah di tebak = Karena sikapnya gampang berubah-ubah

Terdapat dalam kutipan:

Kutipan Percakapan: "Aku terpaksa bertahan menyalami ribuan tamu. Ah, aku bahkan tidak memerhatikan dia cantik atau tidak Yang kubayangkan adalah hari-hari kelam ada di depan mataku.

Keterangan tokoh lain: Aku diam tak bergerak ketika tak sengaja tangan Mas Birru terkulai di pahaku. Tubuhku bergetar hebat tapi dia tak tahu. Mas Birru makan dengan lahap sampai dahinya berkeringat. Pucuk-pucuk hidungnya basah. Aku berdebar melihat keringatnya menetes"

Tegas $=$ Karena sangat menjaga prinsip dalam bekerja.

Terdapat dalam kutipan:

Kutipan percakapan: "Rumusnya gini lho, Zak. Masiyo letaknya di pelosok desa, asal pesantren itu punya pendidikan formal pasti senang kalau jurnalistiknya dikembangkan secara professional"

Menawan = "Karena Mas Birru lelaki yang sempurna dimata Suhita"

Terdapat dalam kutipan: 
Keterangan tokoh lain: "Ia makin menawan karena peluh menetes di dahi dan pelipisnya. Sudut-sudut kaosnya basah terbasuh keringat. Lalu wajahnya yang putih terlihat kian bersinar. Waktu itu aku sangat penasaran siapa dia dan dari mana asalnya. Aku tidak bisa menyibak massa aksi untuk menemukan orang yang kumintai informasi. Ternyata orang itu bernama Gus Birru dan sekarang ada di depanku. Dekat sekali”

Rengganis

Tahu diri

Kutipan Percakapan: "Aku sangat mencintai pekerjaanku, tapi aku tidak bisa berlama-lama ada di lingkaran Mas Birru. Sebab dia sedang susah payah membangun rumah tangganya. Dia sedang berjuang melupakanku dan aku akan berusaha melupakanya"

Keterangan tokoh lain: "Kutelepon berkali-kali tapi hapenya off. Kopi kubiarkan dingin. Selera makanku pun lenyap. Aku berduka menyadari diamdiam Rengganis seperti ingin keluar dari garis edarku"

Jenius

Kutipan percakapan: "Aku senang mengangkat hal ini sebab pada zaman dulu jumlah perempuan yang tinggal di istana sering dibahas dalam laporan Belanda. Apalagi hal-hal ini seolah sudah jadi ciri khas keraton Jawa Tengah bagian selatan. Aku tidak tertarik poligami, jadi yang kubahas bukan tentang selir atau garwa ampeyan. Aku membahas tentang korp Prajurit Estri alias prajurit perempuan yang hebat-hebat"

Cantik

Keterangan tokoh lain: "Kalau kau lihat fotonya, kau pasti akan mencintainya. Semua orang akan jatuh cinta kepadanya. Ia memiliki kecantikan yang tak biasa. Seraut wajah oval. Pipi kemerahan berlesung. Sebuah mulut mungil laksana buah ceri. Aslinya indah. Di foto itu, ia duduk di bawah pohon rindang sambil menyilangkan kaki. Jilbabnya berkibar kena desau angin. Tubuhnya molek seperti puteri-puteri dalam sampul novel Belanda"

Aruna Citrawati

Baik 
Kutipan Percakapan: "Aku adalah perempuan biasa saja. Dengan kehidupan rumah tangga yang biasa saja. Dan bisnis yang juga biasa saja. Tak jauh beda dengan orang kebanyakan"

Keterangan tokoh lain : “Aruna tidak berubah sejak zaman mondok. Dia ceria. Molek. Pemberani. Khas putera-puteri saudagar"

Periang

Kutipan percakapan: "Kang Dharma? Ya ampuuun ... apa kabar,kang? Sudah nikah? Rumah Kang Dharma dekat sini, ya?” Dia memekik memanggil namaku. Beberapa orang menoleh kea rah kami, lalu dia menutup mulutnya saat menyadari suaranya terlalu lantang"

Kang Dharma

Tenang

Keterangan tokoh lain: "Aku tak berani menafsiri itu pertanda apa. Selama mengenalnya, aku tahu dia orang yang setenang Yudhistira. Apa pun yang di dalam hatinya, orang tidak tahu. Ia hanya tampilkan wajah damai”

Dewasa

Kutipan percakapan: "Tapi tadi sore, kekhatiran tampak begitu jelas dari matanya. Mungkin saking parahnya tangisku. Meskipun dia hanya bicara seperlunya kepadaku. Dia selalu bisa menahan diri untuk tidak bertanya apa yang menimpaku. Dan aku selalu menangis karena tahu, dia sangat menghormatiku dalam rindunya"

- Alina Suhita ( Keadaan jiwannya sedih)

Kutipan percakapan: "Saat aku berusaha keras membangun kerajaanya dan menjalankan peran yang seharusnya jadi tanggung jawabnya, dia justru berusaha keras menciptakan suasana beku yang membuat batinku tak lagi punya daya bertahan"

Kutipan percakapan ke-2: "Setiap aku ingin pergi, aku ingat abah dan ummik mendamba putra mahkota lahir dari rahimku. Wajah mas Birru dengan rambut dan kulit bersihnya akan mewarisi ke putera-putri kami. Aku tak boleh tenggelam dalam nestapa sebab namaku Suhita, Dewi Suhita yang membuat Candi Sukuh dan Candi Ceta di lereng Gunung Lawu. Aku mewarisi namanya" 
Kutipan percakapan ke-3: "Kali ini suara santri puteri mendengung, mengaji, dan menyetor hapalan tidak bisa mengurangi resahku. Foto kiriman Aruna seakan menjelaskan banyak hal. Aku menatap foto itu berulang-ulang sambil gemetaran. Apakah melunaknya Mas Birru kemarin karena dia sedang menyembunyikan sesuatu? Senyum terakhirnya pada saat pamitan kemarin terasa tulus, tapi bisa saja itu karena dia sedang menyimpan sebuah rencana”

\section{Al Birruni (Keadaan jiwannya bimbang)}

Kutipan percakapan: “Aku membiarkannya, tidak menyentuhnya. Sebab aku butuh waktu. Aku sedang belajar mendidik diriku sendiri untuk meneriam kenyataan. Bahwa bagaimana pun dia adalah istriku, pilihan orang tuaku. Mereka menunggu keturunan kami. Aku tidak boleh main-main. Perasaanku harus tenang, benihku harus matang. Aku harus mampu memberinya kasih sayang yang utuh dulu sebelum kulakukan kewajibanku. Kalau aku gagal, berarti dia bukan orang yang tepat"

Kutipan percakapan ke-2: “Alina dengar aku. Aku memang egois. Aku minta maaf tapi kamu harus tau sejak awal kita menikah, aku terus berusaha menerima keadaan ini, sampai di Bandung kemarin aku tersadar, tidak hanya ummik dan Al Anwar yang butuh kamu. Tapi aku juga. Aku pribadi memang sayang kamu walaupun sangat terlambat"

Kutipan percakapan ke-3: "Nama ini ada dalam kehidupan abah dan ummik seperti sebuah senjata keramat. Nama ini muncul saat abah dan ummik butuh harapan baru. Mereka berdua membahas nama ini melebihi mereka membahas namaku"

Rengganis (Keadaan jiwannya sedih)

Kutipan percakapan: "Setiap kali aku sedih, aku akan mengingat perempuan-perempuan hebat yang kupikir jauh lebih sedih. Seperti Lady Jane Grey. Seorang ratu Inggris yang berkuasa hanya Sembilan hari lalu hidupnya berakhir dengan tragis. Kalau sudah begitu, aku berpikir, sedihku ini tidak ada apa-apanya. Selagi Mas Birru masih berpijak di bumi, bahagia, maka aku harus bahagia. Tak peduli walaupun kenangan tentang kebersamaan kami 
terus memangsaku. Walaupun bayangannya terus menyergapku. Aku harus yakin, waktu adalah penyembuh terhebat untuk segala macam rasa sakit"

Kutipan percakapan ke-2: "Kisah perpisahan memang tidak pernah sama di hati setiap manusia. Ada yang terasa pedih karena cinta mereka hanya sekedar mengisi waktu. Ada pula yang seperti aku ini. Pedih, karena memang cinta kami kuat, tapi aku terus mencoba mengikhlaskannya. Bukan melupakannya tentu saja. Sebab melupakannya adalah kemustahilan. Aku belajar banyak hal. Aku menyukai tantangan-tantangan baru, tapi aku sadar, belajar melupakan seseorang adalah pelajaran yang paling sulit"

Kutipan percakapan ke-3: "Kupikir dalam hidupku momen paling menyayat adalah saat dia pamit pergi dari kehidupanku untuk menikahi perempuan lain. Ternyata ada yang lebih berat, yaitu pertemuan pertama setelah perpisahan kami. Dalam keadaan dia sudah menikah, sementara namanya di hatiku, belum bisa benar-benar pergi. Dia tak boleh tahu soal ini”

Aruna Citrawati (Keadaan jiwannya sedih)

Kutipan percakapan: "Tapi ayahku, yang alumnus pesantren, malah ceramah panjang lebar. Beliau bilang, meski ayah bisa membayar seratus guru diniyah untuk dating ke rumah, kamu harus mondok sebab di sanalah kamu akan belajar ilmu hidup"

Kutipan percakapan ke-2: "Kata ayahku, ilmu hidup di pesantren, tidak akan kudapat di sekolah manapun. Masku yang mbarep malah nambahnambahi, aku harus dimasukan pesantren yang tua dab besar. Sebab pesantren-pesantren besar jaringan alumninya kuat dan ini akan sangat berharga di kehidupan kami kelak"

Kutipan percakapan ke-3: "Setelah pertemuan itu, aku selalu terbayang, tapi ya, terbayang wajar sih sebagaimana orang awam melihat artis. Alina justru Nampak biasa saja. Enggak kangen atau gimana. Mungkin karena Gus Birru juga selalu menghindar"

Kang Dharma ( Keadaan jiwannya tenang)

Kutipan percakapan: "Dari kejauhan, aku melihatnya berjalan lunglai lalu menghambur ke pelukan Aruna. Sepertinya, ia menceritakan sesuatu yang sangat penting. Dukanya bahkan membuat orang seperti Aruna 
menangis tersedu. Alina Suhita, aku sangat mengkhawatirkanmu. Tapi kau adalah seorang ratu. Jauh dari jangkauanku"

Kutipan percakapan ke-2: "Aku masih ingat senyumnya saat kalimat itu kulontarkan. Maka, saat sore ini aku bertemu Aruna di luar makam, dan ia mengatakan bahwa Suhita sedang terisak di depan pusara sampai berjam-jam, sementara Gus Birru tak di sampingnya, aku tahu, ini adalah firasat tidak baik"

Kutipan percakapan ke-3: "Run, kalau saja kamu tahu, sebelum kupastikan sahabatmu itu bahagia di kerajaannya"

Latar dan tempat sebagai berikut:

Parkiran pondok

Terdapat dalam kutipan:

"Parkiran kami dipenuhi mobil abah, Mas Birru, ummik, dan mobil pondok berderet-deret. Jadi mobil itu berhenti tepat di depan kantor diniyah.”

Toko buku

Terdapat dalam kutipan:

“Aku belanja buku dengan gusar karena dia hanya memberiku waktu dua jam. Ummik meminta Mas Birru menemaniku tapi ia hanya menunggu di mobil."

\section{SPBU}

Terdapat dalam kutipan:

"Ia membelokan mobil ke sebuah SPBU lalu turun dan berlari kecil menuju toilet. Seperti biasa, ia tak mengatakan apa-apa. Bahkan untuk sekedar pamit."

Gazebo

Terdapat dalam kutipan:

"Pelanggan mulai datang menduduki kursi-kursi kayu. Gazebo bamboo beratap ijuk mulai dipenuhi segerombolan anak muda yang tergelak-gelak bahagia."

Masjid Jami' Tegalsari

Terdapat dalam kutipan: 
“Aku bertemu Aruna saat dia sedang selfi di dekat serambi Masjid Jami' Tegalsari, tak jauh dari batu tangga peninggalan kerajaan Majapahit terpasang. Kupikir dia hendak menghampiriku tapi ternyata dia melanjutkan selfi-nya di bangunan kuno beratap limasan sebelah timur masjid"

Tempat tidur

Terdapat dalam kutipan:

“Aku menunduk di tepi ranjang. Dia berdiri sambil besedekap di depan lemari. Ranjangku dipenuhi ribuan kelopak kembang mawar untuk malam pertama kami, tapi kalimatnya menusukku dengan duri-duri tajam. Aku menunduk."

Kamar mandi

Terdapat dalam kutipan:

"Dia berdiri di ambang pintu kamar mandi. Menekan kaki basahnya pada keset yang sudah kuganti baru sambil mengusap rambutnya pakai handuk. Kulihat bulu dadanya berkilat-kilat. Ada rasa yang tiba-tiba hangat menjalar di pusat tubuhku."

\section{Kantor}

Terdapat dalam kutipan:

"Seharian ini acaraku sangat padat. Aku harus menghadiri rapat di beberapa tempat secara bergantian. Di kantor, lay quter kami menikah, yang satunya lagi pindah rumah. Ketua tim pemasaran sudah semingguan ini sakit. Jadi banyak buku terbit sedikit mundur dari jadwal dan hapeku tak henti berdering, berisi pesan orang-orang yang meminta kepastian."

Latar suasana

Mengharukan

Terdapat dalam kutipan:

"Aku menunduk sambil memberinya senyum termanis. Dia tak boleh tahu bahwa aku masih perawan. Dia tak boleh tahu bahwa putra tunggalnya, sama sekali belum menyentuhku. Padahal usia pernikahan kami sudah tujuh bulan lamanya. Aneh memang, mestinya bulan-bulan pertama pernikahan adalah hari-hari paling indah. Penuh gelora, hasrat, keringat, desah 
kenikmatan, kecupan, dan pelukan. Sudah semestinya melingkupi hari-hari pengantin baru manapun."

Menahan rasa sedih

Terdapat dalam kutipan:

"Dia tidak tahu, aku sekarang sudah tidak merdeka. Bahkan untuk menginap ke rumah ibuku pun, aku harus menunggu ummik mengizinkan atau tidak. Aku juga tidak akan bisa leluasa menelepon Aruna. Bagaimana kalau abah atau ummik dengar? Dukaku kusimpan. Dendamku kupendam. Isakku kutahan. Aku harus tampil bahagia. Aku cuma mengiyakan dan bilang pada Aruna, kalau ada apa-apa aku akan WA tapi tidak dengan kalimat panjang, sebab aku tak bisa pegang hp lama-lama kalau Mas Birru di dekatku. Aku jengah kalau Mas Birru terlalu fokus ke hapenya. Jadi aku tidak melakukan itu biar Mas Birru belajar bagaimana memperlakukan orang lain.”

Bahagia

Terdapat dalam kutipan:

“Aku menoleh. Menatapnya lekat. Sinar mata yang dulu selalu sinis, kini sudah melembut. Bibir yang sudah sejak lama hanya bisa kunikmati dari kejauhan, kini begitu dekat. Alis lebat yang dulu selalu membuatku berdebar kini bisa kusentuh dengan perasaan bahagia. Jambang dan rambut ikalnya, selalu memesonaku dari awal pernikahan kami. Aku menyentuhkan ujungujung jari-jariku ke rambut halus di puncak dadanya yang masih basah. Dia tersenyum."

\section{Simpulan Dan Saran}

Novel Hati Suhita karya Khilma Anis ini terdiri atas tokoh dan penokohan yakni dengan tokoh utama bernama Alina Suhita digambarkan sebagai tokoh yang sabar, pintar, dan tawadhu. Adapun tokoh tambahannya adalah Gus Albirruni, Rengganis, Aruna, dan Kang Dharma.

Latar tempat novel Hati Suhita karya Khilma Anis yaitu Parkiran pondok, Toko buku, SPBU, Gazebo, Masjid Jami’Tegalsari, Tempat tidur, Kamar mandi, dan Kantor. 
Setelah mengalami periode yang kelam tokoh Suhita mengambil keputusan tidak akan kembali ke kondisi sebelumnya, karena psikologi kejiwaannya telah mengalami kisah yang lengkap dari sebuah perjalanan hidup manusia.

Sehubungan dengan dilakukannya penelitian maka penulis menyarankan bahwa: pertama, kepada penelaah sastra disarankan untuk mengkaji lebih mendalam tentang adanya nilai-nilai tersirat maupun tersurat dalam novel Hati Suhita karya Khilma Anis, karena dengan begitu kita sebagai pembaca dapat memahami pesan pengarang dan karyanya secara totalitas. Kedua, penelitian ini dapat membantu pembaca memahami isi yang terkandung dalam novel Hati Suhita karya Khilma Anis, sedangkan bagi penulis sastra yang menyangkut kejiwaan tokoh merupakan aspek menarik dalam novel ini. Sehingga penulis sastra untuk seterusnya dapat menjadikan hal ini sebagai referensi tambahan dalam menulis sastra.

\section{Daftar Pustaka}

Albertine Minderop. 2015. Psikologi Sastra. Jakarta: Yayasan Pustaka Obor Indonesia.

Aminuddin. 2011. Pengantar Apresiasi Karya Sastra. Bandung: Sinar Baru Algesindo.

Endaswara, Suwardi. 2013. Metodologi Penelitian Sastra: Espitemelogi, Model Teori, dan Aplikasi. Yogyakarta: Caps.

Faruk. 2005. Pengantar Sosiologi Sastra. Yogyakarta: Pustaka Belajar.

Jabrohim, dkk. 2009. Cara Menulis Kreatif. Yogyakarta: Pustaka Belajar.

Mahsun. 2017. Metode Penelitian Bahasa. Depok: Raja Grafindo Persada.

Moh. Syamsul Ma'arif, S. Q. R. (2021). Kajian Fonologi Bahasa Indonesia dalam Kumpulan Video Mak Beti Karya Arif Muhammad. PENEROKA, 1(01), 151-170.

Nurhayati. 2013. Apreisiasi Prosa Fiksi Indonesia. Surakarta: Cakrawala Media.

Nurgiyantoro, Burhan. 2000. Teori Pengkajian Fiksi. Yogyakarta: UGM. 
Pradopo, Rachmat Djoko. 2013. Beberapa teori sastra, Metode kritik, dan penerapannya. Yogyakarta: Pustaka Belajar.

Sujanto, Agus, dkk. 2009. Psikologi Kepribadian. Jakarta: Bumi Aksara.

Siswantoro. 2010. Metode Penelitian Sastra. Yogyakarta. Pustaka Belajar.

Wiyatmi. 2011. Psikologi Sastra: Teori dan Aplikasinya. Yogyakarta: Kanwa Publisher. 